\title{
EVALUATION OF MINT AND SWEET BASIL HERBS PRODUCTION INTEGRATED INTO THE AQUAPONIC TILAPIA PRODUCTION SYSTEM
}

\section{Sabah A.M. Salama ${ }^{1^{*}}$, Kandel ${ }^{2}$ A.M., El-Shinawy² M.Z., Amer $^{3}$ M.A. and Abul-Soud ${ }^{4}$ M.}

1- Organic Agriculture in English Program, Fac. of Agric., Ain Shams Univ., P.O. Box 68, Hadayek Shoubra 11241, Cairo, Egypt

2- Horticulture Dept., Fac. of Agric., Ain Shams Univ., P.O. Box 68, Hadayek Shoubra 11241, Cairo, Egypt

3- Animal Production Dept., Fac. of Agric., Ain Shams Univ., P.O. Box 68, Hadayek Shoubra 11241, Cairo, Egypt

4- Central Laboratory for Agricultural Climate, Agricultural Research Center, Soilless Dept., Giza, Egypt

${ }^{*}$ Corresponding author: sabahsalama28@yahoo.com

\section{ABSTRACT}

The impacts of climate change combined with water shortage and the need to increase food production to meet increasing population stimulate the implementation of Aquaponic systems not only on food scale but also on some medicinal plants in agriculture production. The current experiment was conducted at the Institute of Graduate Arid Land Agriculture and Research Institute (ALARI) at Ain Shams University, Egypt, to test sweet basil and mint development during the summer seasons of 2017 and 2018 under urban conditions through the aquaponic system. The objective of the study was to investigate the use of aquaponic compared to the chemical nutrient solution (control) as a nutritional source combined with two plant densities $(6$ and 8 plants $/ \mathrm{m}^{2}$ ) in the design of complete randomized blocks for evaluating basil and mint growth. The density of the Nile Tilapia was $100 \mathrm{fish} / \mathrm{m}^{3}$ in the aquaponic facility. The yield characteristics, the nutrient ( $\mathrm{N}, \mathrm{P}$ and $\mathrm{K}$ ) and the oil content (percent) of basil and mint, have been measured in. Reveled results indicated that basil plant had a higher capacity for removing $\mathrm{NH}^{+4}, \mathrm{NO}_{3}, \mathrm{P}$ and $\mathrm{K}$ from fish rearing water than mint while plant density 8 plants $/ \mathrm{m}^{2}$ had a higher capacity compared plant density 6 plants / $\mathrm{m}^{2}$ resulted enhancing the quality of fish rearing water led to increase the fish yield (the final and gain tilapia yield). The chemical nutrient solution provided higher plant height, fresh and dry yields of basil and mint than the aquaponic solution, as well as $\mathrm{N}, \mathrm{P}, \mathrm{K}$, and oil content $\%$ of basil and mint plants in both plant density $\left(6\right.$ and 8 plants $\left./ \mathrm{m}^{2}\right)$ and in both seasons. The composition of aquaponic water as a source of nutrition was not sufficient to meet the requirements for basil and mint nutrients. The highest plant height, $\mathrm{N}, \mathrm{P}, \mathrm{K}$, and oil content results were reported for the treatment of chemical nutrient solution + plant density 6 plants $/ \mathrm{m}^{2}$ while chemical nutrient solution + plant density 8 plants $/ \mathrm{m}^{2}$ had the highest fresh and dry yield of basil and mint. The need for increasing the food production under climate change impacts, the use of aquaponic systems for sweet basil and mint production provided food production (fish and vegetables) as well as the medicinal plants at the same time protecting the environment by avoiding the use of chemical fertilizers.

Keywords: Aquaponic system; Sweet Basil; Mint; Hydroponics; Tilapia; Plant Density; Recirculating Closed System

\section{INTRODUCTION}

World Population and food security are one of the most difficult challenges facing most countries around the world, as the world's population is rapidly 
increasing by up to 7.7 billion people (Worldometer, 2020), compared to (Bernstein 2011, FAO 2012, 2010) By 2050, the world's population will hit 9.6 billion and the food supply should be increased of about $70 \%$ to $100 \%$. (Carlo Bibbiani et al 2016). Aquaponics is a promising technique because of the symbiotic incorporation of two established food production disciplines: (i) aquaculture, the art of fish farming; and (ii) hydroponics, the cultivation of plants in soil-free water. Aquaponics combines the two in a closed recirculation system (Thorarinsdottir, 2015). Recently, the Aquaponic method is one of the most appropriate solutions to ensure food safety, as two products are delivered from a single system (fish and crops) with reduced water use and fewer environmental impacts, therefore, achieving sustainability in addition provide supernormal quality protein, getting freshwater resources for drinking is becoming a challenge so water must be used rationally when applying modern techniques such as Aquaponic system which reduces water usage for crop production. (Yigit et al 2016), Aquaponic is therefore, a sustainable food production system where conventional aquaculture is mixed. (Radosavljević et al 2014) Popular fish included in Aquaponics are Nile tilapia, canal catfish, rainbow trout, and various carp species. (El-Sayed 2006) Presented that Tilapia has become one of the largest farm-raised fish in Egypt and around the world and plays an imporNH4t role in the international food industry. Tilapia is a warm water fish used for aquaculture production, in particular, the Oreochromis genus, including the Nile tilapia (O. niloticus) and is the most commonly recognized of all tilapia species with hydroponic system (which means growing plants in water e.g. herbs, fruits, and vegetables). (Selek et al 2017) In a symbiotic system, the waste excreted by farmed fish provides nutrients to plants that are hydroponically produced, which in turn purify the water. (David Carlsson, 2013). Aquaculture has recently idealized a key source of revenue of approximately 11 million people (Rivera-Ferre et al 2013; FAO, 2010). In addition, about 1 billion people have a supply of animal protein (Tidwell and Allan, 2012). (WHO, 2002) Estimated that more than 80 per cent of the world's population relies on traditional plant-based medicines, especially in developing countries, as a result of the marketing of medicinal plants is growing rapidly and is subject to an increase from 62 US\$ billion in 2004 to 5 trillion US\$ in 2050. Sweet Basil is recommended in aquaponic systems because it grows rapidly, low to medium nutritional requirements, as well as adapted to aquaponic systems Wilson, 2017.
Sweet basil (Ocimum basilicum L.) belongs to the Lamiaceae family Wogiatzi et al 2011 it is an annual herbal and aromatic plant that contains a range of essential oils. It originated in India and was introduced to Europe in the 12th century. Sweet Basil is currently being grown and refined for oil extraction in many countries such as the USA, Belgium, France and Hungary.

Refereeing to Radosavljević et al 2014 the most common plants that can be successfully grown in the Aquaponics system include (basil, mint, thyme, lettuce, spinach, dill, parsley, rosemary, celery, lavender).

As mentioned by (Harley and Brighton, 1977, Chambers 1992) that Mint (Mentha longifolia L. family Lamiaceae) grows widely in Mediterranean areas, Europe, Australia and North Africa. The plant is a versatile perennial with a peppermint fragrance. It has a creeping rhizome with straight to creeping stems $40-120 \mathrm{~cm}$ long. According to Dilipbhai 2015. Mint has been shown to be the source of $75 \%$ natural menthol, toothpaste, Mouthwashes and pharmaceutical manufacturing The leaves contain $0.2 \%$ of essential oil used for human consumption, especially in the manufacture of teas and condiments, antiseptic, anesthetic, diaphoretic, carminative, febrifugal properties, stomach cancers, rheumatism, cough, rheumatism.

The main objective of this study is to increase the productivity of medicinal and aromatic plants integrated into the aquaponic system, thus achieving healthier crops and fish, decreasing water use and mitigating environmental impacts.

\section{MATERIALS AND METHODS}

The experiment was conducted at the Institute of Graduate Arid Land Agriculture and Research Institute (ALARI) at Ain Shams Univ., Egypt. The trial was performed over two summer seasons in 2017 and 2018 for the cultivation of mint and basil under urban conditions (open roof area).

\subsection{Aquaponic system material}

The Aquaponic method is an integrated system consisting mainly of a substrate culture using perlite as a medium for growing French basil and mint; the aquaculture system consists of a tilapia rearing tanks and filtering unit and the system entities, including: 


\section{Evaluation of mint and sweet basil herbs production integrated}

into the Aquaponic Tilapia production system

\subsubsection{Fish material}

Nile Tilapia (Oreochromis niloticus), Mono sex with average initial weight 18-20 gram for finger was used in this trial. The fish density was 100 tilapias/ $\mathrm{m}^{3}$ of water. The Tilapia was fed three times a day with a full sinking pellet. Tilapia was fed $30 \%$ protein-containing pelleted feed at $4-3 \%$ biomass during various rearing periods.

The feed rate for Tilapia was based on the average weight of the species, as small fish eat more feed than large fish. Periodical mean weight of fish samples was taken every 3 weeks as mentioned by (D'Abramo and Brunson, (1996). Feed intake was $3 \%$ of total biomass (tilapia was fed only 6 days and fast for one day to avoid residues of any uneaten feed.

\subsubsection{Fish rearing tank}

Wooden frame ( $1 \mathrm{~m} \times 2 \mathrm{~m}$ and $50 \mathrm{~cm}$ high) padded with 1000 micron black polyethylene sheet was used as a tilapia rearing tank. The actual total volume of water for each rearing tank was 750 liters. Each rearing tank contained 75 tilapia fish with fish density of 100 fish per $\mathrm{m}^{3}$.

\subsubsection{Mechanical Filtration unit of Tilapia}

Mechanical Filtering units consist of two plastic buckets (18 litter volume) containing a basal layer $(5 \mathrm{~cm})$ of gravel $(0.5-5 \mathrm{ml})$ and the rest fill by perlite. The main objective of the mechanical filtration unit is to eliminate the solid waste from tilapia and unfiltered feeders. The mechanical filter worked partly as a biological filter in order to improve the nitrifica- tion cycle and plant nutrition. No need to direct biological filter regarding low fish density use and rearing water volume.

\subsubsection{Fish aerating equipment}

Each tank was supplied with 3 Poyu air pumps of the AP-005 (5 watts) with 8 liters of air per hour in order to offer sufficient dissolved oxygen (8 - 9 ppm) by Mettler Toledo, model 128, s/no1242 for tilapia in the water. A plastic tube by air-stone connected to the air pump to ensure consistent air delivery.

\subsection{Substrate culture system}

A simple wooden table $(1 \mathrm{~m}$ length $\mathrm{x} 1 \mathrm{~m}$ width $x 0.15 \mathrm{~m}$ depth) was used to present a bed substrate culture as a substrate system. The inside and bottom of the tables were coated with black polyethylene $(0.5 \mathrm{~mm})$ and filled with perlite (volume $150 \mathrm{~L}$ / table) as a medium to provide good aeration and allow fish water to return to the fish tank or nutrient solution in the closed system. The tables were set in slop 1 percent to help collect the leaching water for each plot through a number of holes in the base area.

Fish water and nutrient solution (Abul-Soud et al 2017) were pumped through a submersible pump (40 watts). Table (1) illustrated the chemical composition of nutrient solutions. Plants were irrigated using drip irrigation drippers with a capacity of $4 \mathrm{I} /$ hr. The finishing was scheduled to work 12 hours a day. The planned irrigation was programmed using a wireless timer (10 minutes).

Table 1. The chemical composition of nutrient solutions.

\begin{tabular}{|c|c|c|c|c|c|c|c|c|c|c|c|}
\hline \multirow{2}{*}{$\begin{array}{c}\text { Nutrient } \\
\text { source }\end{array}$} & \multicolumn{4}{|c|}{ Macronutrients (ppm) } & \multicolumn{4}{c|}{ Micronutrients (ppm) } \\
\cline { 2 - 12 } & N & P & K & Ca & Mg & Fe & Mn & Zn & B & Cu & Mo \\
\hline Ch. N.S. & 160 & 40 & 240 & 150 & 48 & 3.0 & 0.8 & 0.4 & 0.5 & 0.25 & 0.02 \\
\hline
\end{tabular}

${ }^{*}$ Ch.N.S: chemical nutrient solution

\subsubsection{Plant Materials}

Sweet basil (Ocimum basilicum var. minimum.) Cassel rock seeds were planted in the middle of March 2017 and 2018. Basil seeds were planted in foam trays (peat moss: perlite 1:1 v/v) Plants were planted in perlite substrate culture after 30 days of sowing. Mint (Mentha longifolia) seedlings were transplanted into substrate culture in mid-April. All mint and basil were cultivated in mid-April 2017 and
2018 and harvested twice in the last week of September 2017 and 2018.

\subsection{The investigated treatments}

The possibilities of growing basil and mint in the aquaponic system compared to the chemical nutrient solution used during two different seasons for each plant under study were explored using the following treatments: 
1- Nutrition Source: Aquaponic Water and Chemical Nutrient Solution (Abul-Soud et al 2017). 2- Plant Density: 6 and 8 plants $/ \mathrm{m}^{2}$.

\subsection{Measurements}

\subsubsection{Recorded data of basil and mint}

Plant samples of each experimental plot were taken to establish the growth parameters at harvest time (two cutting harvest/season were applied for both basil and mint). Plant height $(\mathrm{cm})$, total fresh yield (total 2 cutting harvest (on plant height $10 \mathrm{~cm}$ ) during each season $\left(\mathrm{Kg} / \mathrm{m}^{2}\right.$ ), total dry yield (Air forced oven for 48 hours at $45{ }^{\circ} \mathrm{C}\left(\mathrm{Kg} / \mathrm{m}^{2}\right)$ were determined.

For the mineral analysis of the leaves (N, P and $\mathrm{K}$ percent) it was determined that three plant samples of each plot were dried at $70^{\circ} \mathrm{C}$ in Air forced oven for 48 hours. The dried leaves were digested in $\mathrm{H}_{2} \mathrm{SO}_{4}$ according to the method described by Allen (1974). The amounts of $N, P$ and $K$ in the acid solution have been estimated. Nitrogen was determined by using the micro Kjeldahl method as defined by FAO (1980). Phosphorus content was calculated using a spectrophotometer based on WaNH4abe and Olsen (1965). Potassium content was photo-metrically measured using the Flame Photometer Chapman and Pratt 1962. Basil and mint oil contents were estimated by Ds Chromium 6200 Gas Chromatograph.

\subsubsection{Recorded data of Fish}

Three samples tilapia fish rearing water were collected to estimate monthly $\mathrm{NH}^{+4}: \mathrm{NO}_{3}, \mathrm{P}$ and $\mathrm{K}$ (ppm) concentrations of fish water tank regarding Rosanna Sallenave, 2016, Skar et al 2015. While the parameters of tilapia growth performance were estimated as follows:

\section{- Total weight gain (TG)}

(TG) $g=W 1-$ W0 As W1 the final weight $(g)$. $\mathrm{WO}=$ the initial weight $(\mathrm{g})$.

\section{- Average daily gain (ADG)}

$A D G=(W 1-W 0) /$ days of feeding in the experimental periods

\section{- Specific growth rate (SGR)}

SGR $\%=100$ (Ln final weight - Ln initial weight)/period (days)

\section{Feed utilization parameters}

- Feeding conversation ratio (FCR)

FCR $=$ Feed intake $(\mathrm{g}) /$ Weight gain $(\mathrm{g})$

\section{- Survival rate (SR)}

$\mathrm{SR}=$ (No. of fish at the final /No. of fish at the initial * 100

\subsection{Statistical design and analysis}

Data analysis was done by using ANOVA statistical analysis program for a completely randomized plots design. The LSD among means was tested for significance at 0.05 levels according to Snedicor and Cochran (1980).

\section{RESULTS}

Table (2 and 3) presented the average fish rearing water parameters $\left(\mathrm{NH}^{+4}, \mathrm{NO}_{3}, \mathrm{P}, \mathrm{K}, \mathrm{pH}\right.$ and $\left.\mathrm{Ec}\right)$ under different plant densities (6 and 8 plants $/ \mathrm{m}^{2}$ ) of mint and basil during the two seasons. The obtained results showed that increasing the plant density from 6 to 8 plants per Sq. $\mathrm{m}$ led to decrease $\mathrm{NH}^{+4}$, $\mathrm{NO}_{3}, \mathrm{P}$ and $\mathrm{K}$ (ppm) contents of fish rearing water as logical result of increasing the plant nutrient requirements. The results also revealed that increasing the $\mathrm{NO}_{3}, \mathrm{P}$ and $\mathrm{K}$ during the season regarding increasing the fish biomass and the increase of the feeding rate of fish while $\mathrm{NH}^{+4}$ had reverse direction could be explained depending on enhancing the efficiency of biology filter.

Needless to mention that compared to the chemical composition of nutrient solution (Table 1), $\mathrm{NO}_{3}$ and $\mathrm{K}$ contents of fish rearing water approximately close to their contents in chemical nutrient solution while $\mathrm{P}$ content of fish rearing water was presented much less than its content of the chemical nutrient solution. These results provide the evidence on the positive effects of chemical nutrient solution on the growth and yield of mint and basil compared to fish rearing water.

Compared the records of fish rearing water of mint (Table 2) and basil (Table 3) instead of plant density, the $\mathrm{NH}^{+4}, \mathrm{NO}_{3}, \mathrm{P}, \mathrm{K}, \mathrm{pH}$ and $\mathrm{EC}$ contents of fish rearing water with mint were less than contents of fish rearing water with basil. Basil plants showed higher capacity on removing $\mathrm{NH}^{+4}, \mathrm{NO}_{3}, \mathrm{P}$ and $\mathrm{K}$ from fish rearing water than mint. Enhancing the fish rearing water quality resulted in increasing the fish yield via increasing the plant density from 6 to 8 plants $/ \mathrm{m}^{2}$ and the use of the high capacity plants for removing $\mathrm{NH}^{+4}, \mathrm{NO}_{3}, \mathrm{P}$ and $\mathrm{K}$ from fish rearing water. 

into the Aquaponic Tilapia production system

Table 2. Average fish rearing water parameters under different plant densities of basil

\begin{tabular}{|c|c|c|c|c|c|c|c|c|c|c|}
\hline \multirow{3}{*}{$\frac{\text { Basil }}{\text { Plant density }}$} & \multicolumn{5}{|c|}{ First season } & \multicolumn{5}{|c|}{ Second season } \\
\hline & April & May & June & July & August & April & May & June & July & August \\
\hline & \multicolumn{10}{|c|}{ NH4 (ppm) } \\
\hline 6 plants $/ \mathrm{m}^{2}$ & $9.43 \mathrm{~A}$ & 10.66B & $9.24 \mathrm{~A}$ & $9.18 \mathrm{~A}$ & $8.45 \mathrm{~A}$ & $9.53 \mathrm{~A}$ & $10.34 \mathrm{~A}$ & $9.29 \mathrm{~A}$ & $9.24 \mathrm{~A}$ & $8.49 \mathrm{~A}$ \\
\hline \multirow[t]{2}{*}{8 plants $/ \mathrm{m}^{2}$} & $9.30 \mathrm{~B}$ & $10.48 \mathrm{~A}$ & $9.13 \mathrm{~B}$ & $9.08 \mathrm{~B}$ & $8.36 \mathrm{~B}$ & 9.37B & 10.27B & $9.18 \mathrm{~B}$ & $9.12 \mathrm{~B}$ & 8.37B \\
\hline & \multicolumn{10}{|c|}{$\mathrm{NO}_{3}$ (ppm) } \\
\hline 6 plants $/ \mathrm{m}^{2}$ & $80.78 \mathrm{~A}$ & $147.11 \mathrm{~A}$ & $122.12 \mathrm{~A}$ & $136.13 \mathrm{~A}$ & 144.32A & $84.55 \mathrm{~A}$ & 156.17A & $129.32 \mathrm{~A}$ & $141.18 \mathrm{~A}$ & $159.56 \mathrm{~A}$ \\
\hline \multirow[t]{2}{*}{8 plants $/ \mathrm{m}^{2}$} & 75.26B & 136.44B & 116.21B & 129.24B & 136.24B & $79.32 B$ & 141.32B & 119.34B & $131.25 \mathrm{~B}$ & 143.33B \\
\hline & \multicolumn{10}{|c|}{$P$ (ppm) } \\
\hline 6 plants $/ \mathrm{m}^{2}$ & $1.44 \mathrm{~A}$ & $3.23 \mathrm{~A}$ & $2.83 \mathrm{~A}$ & $4.62 \mathrm{~A}$ & $5.23 \mathrm{~A}$ & $1.46 \mathrm{~A}$ & $3.84 \mathrm{~A}$ & $3.34 \mathrm{~A}$ & $5.02 \mathrm{~A}$ & $6.94 \mathrm{~A}$ \\
\hline \multirow[t]{2}{*}{8 plants $/ \mathrm{m}^{2}$} & $1.26 \mathrm{~B}$ & 2.74B & 2.27B & 3.93B & $4.82 \mathrm{~B}$ & $1.30 \mathrm{~B}$ & $3.63 \mathrm{~B}$ & $2.93 \mathrm{~B}$ & 4.54B & $5.14 \mathrm{~B}$ \\
\hline & \multicolumn{10}{|c|}{ K (ppm) } \\
\hline 6 plants $/ \mathrm{m}^{2}$ & $120 \mathrm{~A}$ & $154 \mathrm{~A}$ & $142 \mathrm{~A}$ & $167 \mathrm{~A}$ & $188 \mathrm{~A}$ & $124 \mathrm{~A}$ & $159 A$ & $147 \mathrm{~A}$ & $171 \mathrm{~A}$ & $192 A$ \\
\hline \multirow[t]{2}{*}{8 plants $/ \mathrm{m}^{2}$} & $114 \mathrm{~B}$ & 149B & 133B & 158B & $178 \mathrm{~B}$ & 117B & 151B & 142B & 164B & 184B \\
\hline & \multicolumn{10}{|c|}{ Average $\mathrm{pH}$} \\
\hline 6 plants $/ \mathrm{m}^{2}$ & $7 A$ & $7.1 \mathrm{~A}$ & $7.3 \mathrm{~A}$ & $6.9 \mathrm{~A}$ & $6.5 \mathrm{~A}$ & $7.1 \mathrm{~A}$ & $6.9 \mathrm{~A}$ & $6.7 \mathrm{~A}$ & $6.5 \mathrm{~A}$ & $6.6 \mathrm{~A}$ \\
\hline \multirow[t]{2}{*}{8 plants $/ \mathrm{m}^{2}$} & $6.8 \mathrm{~B}$ & 7B & $6.9 \mathrm{~B}$ & $7.2 \mathrm{~B}$ & $6.6 \mathrm{~B}$ & $6.5 \mathrm{~B}$ & $6.8 \mathrm{~B}$ & $7.3 \mathrm{~B}$ & $7.1 \mathrm{~B}$ & $6.8 \mathrm{~B}$ \\
\hline & \multicolumn{10}{|c|}{ E.C ds $\mathrm{m}^{-1}$} \\
\hline 6 plants $/ \mathrm{m}^{2}$ & $0.50 \mathrm{~A}$ & $0.58 \mathrm{~A}$ & $0.64 \mathrm{~A}$ & $0.66 \mathrm{~A}$ & $0.62 \mathrm{~A}$ & $0.51 \mathrm{~A}$ & $0.61 \mathrm{~A}$ & $0.66 \mathrm{~A}$ & $0.69 \mathrm{~A}$ & $0.65 \mathrm{~A}$ \\
\hline 8 plants $/ \mathrm{m}^{2}$ & $0.50 \mathrm{~B}$ & $0.56 \mathrm{~B}$ & $0.61 \mathrm{~B}$ & $0.63 \mathrm{~B}$ & $0.60 \mathrm{~B}$ & $0.51 \mathrm{~B}$ & $0.58 \mathrm{~B}$ & $0.66 \mathrm{~B}$ & $0.67 \mathrm{~B}$ & $0.63 \mathrm{~B}$ \\
\hline
\end{tabular}

Table 3. Average fish rearing water parameters under different plant densities of Mint

\begin{tabular}{|c|c|c|c|c|c|c|c|c|c|c|}
\hline \multirow{3}{*}{\begin{tabular}{|c|} 
Mint \\
Plant density
\end{tabular}} & \multicolumn{5}{|c|}{ First season } & \multicolumn{5}{|c|}{ Second season } \\
\hline & April & May & June & July & August & April & May & June & July & August \\
\hline & \multicolumn{10}{|c|}{$\mathrm{NH}^{+4}$ (ppm) } \\
\hline 6 plants $/ \mathrm{m}^{2}$ & $1.44 \mathrm{~B}$ & $1.53 \mathrm{~B}$ & $1.62 \mathrm{~B}$ & $1.68 \mathrm{~B}$ & 1.73B & $1.47 \mathrm{~B}$ & 1.57B & $1.63 \mathrm{~B}$ & $1.70 \mathrm{~B}$ & $1.72 \mathrm{~A}$ \\
\hline \multirow[t]{2}{*}{8 plants $/ \mathrm{m}^{2}$} & $1.56 \mathrm{~A}$ & $1.61 \mathrm{~A}$ & $1.68 \mathrm{~A}$ & $1.71 \mathrm{~A}$ & $1.76 \mathrm{~A}$ & $1.59 \mathrm{~A}$ & $1.62 \mathrm{~A}$ & $1.66 \mathrm{~A}$ & $1.76 \mathrm{~A}$ & $1.79 \mathrm{~B}$ \\
\hline & \multicolumn{10}{|c|}{$\mathrm{NO}_{3}(\mathrm{ppm})$} \\
\hline 6 plants $/ \mathrm{m}^{2}$ & $72.6 \mathrm{~A}$ & $132.2 \mathrm{~A}$ & 120.0A & $148.0 \mathrm{~A}$ & $161.6 \mathrm{~A}$ & $77.6 \mathrm{~A}$ & $138.3 \mathrm{~A}$ & $129.1 \mathrm{~A}$ & $157.1 \mathrm{~A}$ & $167.1 \mathrm{~A}$ \\
\hline \multirow[t]{2}{*}{8 plants $/ \mathrm{m}^{2}$} & $62.2 \mathrm{~B}$ & 125.4B & 110.2B & 133.1B & 146.4B & $67.3 \mathrm{~B}$ & $130.2 B$ & 127.3B & 140.2BB & 158.3B \\
\hline & \multicolumn{10}{|c|}{ P (ppm) } \\
\hline 6 plants $/ \mathrm{m}^{2}$ & $1.34 \mathrm{~A}$ & $2.52 \mathrm{~A}$ & $2.83 \mathrm{~A}$ & $3.84 \mathrm{~A}$ & $4.43 \mathrm{~A}$ & $1.38 \mathrm{~A}$ & $2.73 \mathrm{~A}$ & $3.64 \mathrm{~A}$ & $4.75 \mathrm{~A}$ & $5.54 \mathrm{~A}$ \\
\hline \multirow[t]{2}{*}{8 plants $/ \mathrm{m}^{2}$} & $1.31 \mathrm{~B}$ & $2.01 \mathrm{~B}$ & $2.43 \mathrm{~B}$ & $3.23 \mathrm{~B}$ & 3.83B & $1.33 \mathrm{~B}$ & $2.32 \mathrm{~B}$ & $3.13 \mathrm{~B}$ & $4.13 \mathrm{~B}$ & $4.78 \mathrm{~B}$ \\
\hline & \multicolumn{10}{|c|}{$\mathrm{K}$ (ppm) } \\
\hline 6 plants $/ \mathrm{m}^{2}$ & $117 A$ & $149 \mathrm{~A}$ & $138 \mathrm{~A}$ & $161 \mathrm{~A}$ & $176 \mathrm{~A}$ & $122 \mathrm{~A}$ & $152 \mathrm{~A}$ & $145 \mathrm{~A}$ & $169 \mathrm{~A}$ & $180 \mathrm{~A}$ \\
\hline \multirow[t]{2}{*}{8 plants $/ \mathrm{m}^{2}$} & $110 \mathrm{~B}$ & 141B & $130 \mathrm{~B}$ & $162 \mathrm{~B}$ & 169B & $118 \mathrm{~B}$ & 148B & 137B & 166B & $173 \mathrm{~B}$ \\
\hline & \multicolumn{10}{|c|}{ Average $\mathrm{pH}$} \\
\hline 6 plants $/ \mathrm{m}^{2}$ & $6.7 \mathrm{~A}$ & $6.9 \mathrm{~A}$ & $7 A$ & $7.4 \mathrm{~A}$ & $7.1 \mathrm{~A}$ & $7.1 \mathrm{~A}$ & $7.3 \mathrm{~A}$ & $7.1 \mathrm{~A}$ & $6.4 \mathrm{~A}$ & $6.3 \mathrm{~A}$ \\
\hline \multirow[t]{2}{*}{8 plants $/ \mathrm{m}^{2}$} & $6.5 \mathrm{~B}$ & $6.8 \mathrm{~B}$ & $7.2 \mathrm{~B}$ & $7.1 \mathrm{~B}$ & $6.9 \mathrm{~B}$ & $6.5 \mathrm{~B}$ & $7.5 \mathrm{~B}$ & $6.3 \mathrm{~B}$ & $6.6 \mathrm{~B}$ & $6.8 \mathrm{~B}$ \\
\hline & \multicolumn{10}{|c|}{ E.C ds $\mathrm{m}^{-1}$} \\
\hline 6 plants $/ \mathrm{m}^{2}$ & $0.50 \mathrm{~A}$ & $0.53 B$ & $0.61 \mathrm{~A}$ & $0.63 \mathrm{~B}$ & $0.62 \mathrm{~A}$ & $0.51 \mathrm{~A}$ & $0.59 \mathrm{~A}$ & $0.63 \mathrm{~A}$ & $0.65 \mathrm{~A}$ & $0.65 \mathrm{~A}$ \\
\hline 8 plants $/ \mathrm{m}^{2}$ & $0.50 \mathrm{~A}$ & $0.52 \mathrm{~B}$ & $0.58 \mathrm{~B}$ & $0.62 B$ & $0.60 \mathrm{~A}$ & $0.51 \mathrm{~A}$ & $0.54 \mathrm{~B}$ & $0.60 \mathrm{~B}$ & $0.64 \mathrm{~B}$ & $0.62 \mathrm{~B}$ \\
\hline
\end{tabular}


The findings in Table (4) showed the effect of plant density $\left(6\right.$ and 8 plants $/ \mathrm{m}^{2}$ ) of basil and mint on total tilapia fish yield $(75 \mathrm{fish} / \mathrm{kg})$, respectively. The rise in plant density from 6 to 8 plants $/ \mathrm{m}^{2}$ of both basil and mint led to an increase in total tilapia fish yield. Plant density 8 plants $/ \mathrm{m}^{2}$ produced higher yields of tilapia fish in both seasons as well as basil and mint regarding to the higher capacity of removing nutrients of fish water tank and avoid the different biohazards on fish production. Final weight gain (FW), Total weight gain (TG), Average daily gain (ADG), Specific growth rate \% (SGR) of Tilapia was higher in plant density 8 plants $/ \mathrm{m}^{2}$ than plant density 6 plants $/ \mathrm{m}^{2}$ for both basil and mint in the first and second season. Basil plants had significant positive effects on FW and TG compared to mint plants.

Meanwhile, feeding conversation ratio \% (FCR) was on contrast as it was lower in plant density 8 plants $/ \mathrm{m}^{2}$ than plant density 6 plants $/ \mathrm{m}^{2}$ for the two plant types ( basil and mint) for both seasons. There is no significant difference in Survival rate \% (SR) of tilapia integrated with both plant types in both seasons.

As regards in Table (5) the impact of plant density, the increase in plant density from 6 to 8 plants has increased the fresh and dry yield of basil but decreased the oil content of basil plants. By comparison, the decline in plant density from 8 to 6 plants led to an increase in N, P, K and oil content (percent).

The highest plant height, N, P, K and oil content results were reported by the treatment of chemical nutrient solution + plant density 6 plants $/ \mathrm{m}^{2}$ while chemical nutrient solution + plant density 8 plants / $\mathrm{m}^{2}$ had the highest fresh and dry yield of basil. On the other hand, the lowest values of $\mathrm{N}, \mathrm{P}, \mathrm{K}$ and oil contents (\%) illustrated by aqua water + plant density 8 plants $/ \mathrm{m}^{2}$.

Results in Table (6) showed that Mint's plant height in the chemical nutrient solution is higher than in aquaponic water and that there is no significant difference between plant density $(6$ and 8 plants $/ \mathrm{m}^{2}$ ) in both nutrient sources (nutrient solution and aquaponic water) in both seasons. New and dry yields are higher in plant density (8 plants / $\mathrm{m}^{2}$ ) than in plant density $\left(6\right.$ plants $\left./ \mathrm{m}^{2}\right)$ in both nutrients.

Forwarding, $\mathrm{N}, \mathrm{P}, \mathrm{K}(\%)$ in plant density (6 plants $\left./ \mathrm{m}^{2}\right)$ is higher than plant density $\left(8\right.$ plants $\left./ \mathrm{m}^{2}\right)$ in both nutrient sources also in both seasons, there is no significant difference in oil percent of both nutrient source and plant density ( 6 and 8 plants $/ \mathrm{m}^{2}$ ) but in aquaponic water (6 plants $\left./ \mathrm{m}^{2}\right)$ it is higher than plant density $\left(8\right.$ plants $\left./ \mathrm{m}^{2}\right)$ in both seasons.

Table 4. The parameters of tilapia growth performance in the aquaponic system with basil and mint

\begin{tabular}{|c|c|c|c|c|}
\hline \multirow[t]{3}{*}{ Treatment } & \multicolumn{2}{|c|}{ Tilapia with basil } & \multicolumn{2}{|c|}{ Tilapia with mint } \\
\hline & First season & Second season & First season & Second season \\
\hline & \multicolumn{2}{|c|}{ Final weight gain $(\mathrm{FW})(\mathrm{Kg})$} & \multicolumn{2}{|c|}{ Final weight gain (FW) $(\mathrm{Kg})$} \\
\hline \multirow{3}{*}{$\begin{array}{l}6 \text { plants } / \mathrm{m}^{2} \\
8 \text { plants } / \mathrm{m}^{2}\end{array}$} & $12.38 \mathrm{~B}$ & $13.11 \mathrm{~B}$ & $10.13 \mathrm{~B}$ & $11.25 \mathrm{~B}$ \\
\hline & $13.66 \mathrm{~A}$ & $14.19 \mathrm{~A}$ & $11.54 \mathrm{~A}$ & $11.53 \mathrm{~A}$ \\
\hline & \multicolumn{2}{|c|}{ Total weight gain (TG)g } & \multicolumn{2}{|c|}{ Total weight gain (TG)g } \\
\hline \multirow{3}{*}{$\begin{array}{l}6 \text { plants } / \mathrm{m}^{2} \\
8 \text { plants } / \mathrm{m}^{2}\end{array}$} & $10.88 \mathrm{~B}$ & $11.61 \mathrm{~B}$ & $8.63 \mathrm{~B}$ & $9.75 \mathrm{~B}$ \\
\hline & $12.16 \mathrm{~A}$ & $12.69 \mathrm{~A}$ & $10.04 \mathrm{~A}$ & $10.03 \mathrm{~A}$ \\
\hline & \multicolumn{2}{|c|}{ Average daily gain (ADG) } & \multicolumn{2}{|c|}{ Average daily gain (ADG) } \\
\hline \multirow{3}{*}{$\begin{array}{l}6 \text { plants } / \mathrm{m}^{2} \\
8 \text { plants } / \mathrm{m}^{2}\end{array}$} & $0.091 \mathrm{~B}$ & $0.097 \mathrm{~B}$ & $0.072 \mathrm{~B}$ & $0.081 \mathrm{~B}$ \\
\hline & $0.101 \mathrm{~A}$ & $0.106 \mathrm{~A}$ & $0.084 \mathrm{~A}$ & $0.084 \mathrm{~A}$ \\
\hline & \multicolumn{2}{|c|}{ Specific growth rate \% (SGR) } & \multicolumn{2}{|c|}{ Specific growth rate \% (SGR) } \\
\hline 6 plants $/ \mathrm{m}^{2}$ & $1.41 \mathrm{~B}$ & $1.72 \mathrm{~B}$ & $1.54 \mathrm{~B}$ & $1.61 \mathrm{~B}$ \\
\hline \multirow[t]{2}{*}{8 plants $/ \mathrm{m}^{2}$} & $1.74 \mathrm{~A}$ & $1.77 \mathrm{~A}$ & $1.63 \mathrm{~A}$ & $1.63 \mathrm{~A}$ \\
\hline & \multicolumn{2}{|c|}{ Feeding conversation ratio (FCR) } & \multicolumn{2}{|c|}{ Feeding conversation ratio (FCR) } \\
\hline 6 plants $/ \mathrm{m}^{2}$ & $1.61 \mathrm{~A}$ & $1.50 \mathrm{~A}$ & $1.94 \mathrm{~A}$ & $1.80 \mathrm{~A}$ \\
\hline \multirow[t]{2}{*}{8 plants $/ \mathrm{m}^{2}$} & $1.45 \mathrm{~B}$ & $1.40 \mathrm{~B}$ & $1.71 \mathrm{~B}$ & $1.71 \mathrm{~B}$ \\
\hline & \multicolumn{2}{|c|}{ Survival rate \% (SR) } & \multicolumn{2}{|c|}{ Survival rate \% (SR) } \\
\hline 6 plants $/ \mathrm{m}^{2}$ & $95.4 \mathrm{~A}$ & $95.3 \mathrm{~A}$ & $95.7 \mathrm{~A}$ & $95.6 \mathrm{~A}$ \\
\hline 8 plants $/ \mathrm{m}^{2}$ & $95.8 \mathrm{~A}$ & $95.5 \mathrm{~A}$ & $95.9 \mathrm{~A}$ & $95.8 \mathrm{~A}$ \\
\hline
\end{tabular}



into the Aquaponic Tilapia production system

The chemical nutrient solution has yielded the highest yields of basil and mint as well as N, P, K and oil contents, but the highest yields of N,P and $\mathrm{K}$ contents may have negative impacts on the yield quality of basil and mint. The composition of aquaponic water as a source of nutrition was not sufficient to meet the requirements for basil and mint nutrients.

Table 5. Effect of plant density and nutrient source on vegetative growth and chemical characteristics of Basil during the cultivated seasons

\begin{tabular}{|c|c|c|c|c|c|c|c|c|}
\hline \multirow[b]{2}{*}{$\begin{array}{l}\text { Nutr. } \\
\text { Source }\end{array}$} & \multirow[b]{2}{*}{$\begin{array}{c}\text { Plant } \\
\text { density }\end{array}$} & \multicolumn{7}{|c|}{ First season 2017} \\
\hline & & $\begin{array}{c}\text { Plant } \\
\text { height. } \\
\text { (cm) }\end{array}$ & $\begin{array}{l}\text { Fresh yield } \\
\qquad \mathrm{Kg} / \mathrm{m}^{2}\end{array}$ & $\begin{array}{l}\text { Dry yield } \\
\mathrm{Kg} / \mathrm{m}^{2}\end{array}$ & $\begin{array}{c}N \\
(\%)\end{array}$ & $\begin{array}{c}\mathbf{P} \\
(\%)\end{array}$ & $\begin{array}{c}K \\
(\%)\end{array}$ & $\begin{array}{l}\text { Oil } \\
(\%)\end{array}$ \\
\hline \multirow{2}{*}{ Ch.N.S } & $6 \mathrm{pl} . / \mathrm{m}^{2}$ & $53.3 \mathrm{~A}$ & $3192.70 \mathrm{~B}$ & $491.00 \mathrm{~B}$ & $1.91 \mathrm{~A}$ & $0.36 \mathrm{~A}$ & $2.04 \mathrm{~A}$ & $0.66 \mathrm{~A}$ \\
\hline & $8 \mathrm{pl} . / \mathrm{m}^{2}$ & $53.0 \mathrm{~A}$ & $4466.70 \mathrm{~A}$ & $687.37 \mathrm{~A}$ & $1.57 \mathrm{C}$ & $0.30 \mathrm{~B}$ & $1.33 \mathrm{C}$ & $0.53 \mathrm{~A}$ \\
\hline \multirow{3}{*}{ Aqua $S$} & $6 \mathrm{pl} . / \mathrm{m}^{2}$ & $40.7 \mathrm{~B}$ & $1704.70 \mathrm{D}$ & $262.33 \mathrm{D}$ & $1.77 \mathrm{~B}$ & $0.31 \mathrm{~B}$ & $1.60 \mathrm{~B}$ & $0.24 \mathrm{~B}$ \\
\hline & $8 \mathrm{pl} . / \mathrm{m}^{2}$ & $42.0 \mathrm{~B}$ & $2587.20 \mathrm{C}$ & $398.13 \mathrm{C}$ & $1.39 \mathrm{D}$ & $0.22 \mathrm{C}$ & $1.08 \mathrm{D}$ & $0.17 \mathrm{~B}$ \\
\hline & & \multicolumn{7}{|c|}{ Second Season 2018} \\
\hline \multirow{2}{*}{ Ch.N.S } & $6 \mathrm{pl} . / \mathrm{m}^{2}$ & $62.0 \mathrm{~A}$ & $3413.00 \mathrm{~B}$ & $524.67 \mathrm{~B}$ & $2.34 \mathrm{~A}$ & $0.43 \mathrm{~A}$ & $2.75 \mathrm{~A}$ & $1.90 \mathrm{~A}$ \\
\hline & $8 \mathrm{pl} . / \mathrm{m}^{2}$ & $60.7 \mathrm{~A}$ & $4637.33 \mathrm{~A}$ & $713.60 \mathrm{~A}$ & $1.66 \mathrm{C}$ & $0.31 \mathrm{~B}$ & $1.49 \mathrm{C}$ & $1.60 \mathrm{~B}$ \\
\hline \multirow{2}{*}{ Aqua $S$} & $6 \mathrm{pl} . / \mathrm{m}^{2}$ & $45.3 \mathrm{~B}$ & $2004.67 \mathrm{D}$ & $308.67 \mathrm{D}$ & $2.07 \mathrm{~B}$ & $0.38 \mathrm{~A}$ & $1.75 \mathrm{~B}$ & $0.48 \mathrm{C}$ \\
\hline & $8 \mathrm{pl} . / \mathrm{m}^{2}$ & $46.7 \mathrm{~B}$ & $2776.00 \mathrm{C}$ & $426.93 \mathrm{C}$ & $1.44 \mathrm{D}$ & $0.25 \mathrm{C}$ & $1.21 \mathrm{D}$ & $0.34 \mathrm{C}$ \\
\hline
\end{tabular}

* Similar letters indicate non-significant at 0.05 levels.

${ }^{* *}$ Capital letters indicate the significant difference of each factor $(P<0.05)$

${ }^{* * *}$ Nutr. Source: nutrient source,

${ }^{* * * *}$ Ch.N.S: chemical nutrient solution

${ }^{* * * * *}$ Aqua S.: Aquaponic solution

Table 6. Effect of plant density and nutrient source on vegetative growth and chemical characteristics of Mint during the cultivated seasons.

\begin{tabular}{|c|c|c|c|c|c|c|c|c|}
\hline \multirow{2}{*}{$\begin{array}{c}\text { Nutr. } \\
\text { Source }\end{array}$} & $\begin{array}{c}\text { Plant } \\
\text { density }\end{array}$ & $\begin{array}{c}\text { Plant } \\
\text { height } \\
(\mathbf{c m})\end{array}$ & $\begin{array}{c}\text { Fresh yield } \\
\mathbf{K g} / \mathbf{m}^{2}\end{array}$ & $\begin{array}{c}\text { Dry yield } \\
\mathbf{K g} / \mathbf{m}^{2}\end{array}$ & $\begin{array}{c}\mathbf{N} \\
(\%)\end{array}$ & $\begin{array}{c}\mathbf{P} \\
(\%)\end{array}$ & $\begin{array}{c}\mathbf{K} \\
(\%)\end{array}$ & $\begin{array}{c}\text { Oil } \\
(\%)\end{array}$ \\
\hline \multirow{2}{*}{ Ch.N.S } & $6 \mathrm{pl} . / \mathrm{m}^{2}$ & $53.3 \mathrm{~A}$ & $1809.33 \mathrm{~B}$ & $278.33 \mathrm{~B}$ & $2.34 \mathrm{~A}$ & $0.34 \mathrm{~A}$ & $2.45 \mathrm{~A}$ & $1.19 \mathrm{~A}$ \\
& $8 \mathrm{pl} . / \mathrm{m}^{2}$ & $53.0 \mathrm{~A}$ & $2529.33 \mathrm{~A}$ & $389.27 \mathrm{~A}$ & $1.80 \mathrm{~B}$ & $0.21 \mathrm{C}$ & $1.45 \mathrm{~B}$ & $1.15 \mathrm{~A}$ \\
\hline \multirow{2}{*}{ Aqua S } & $6 \mathrm{pl} . / \mathrm{m}^{2}$ & $40.7 \mathrm{~B}$ & $1055.33 \mathrm{D}$ & $162.33 \mathrm{D}$ & $2.07 \mathrm{~B}$ & $0.26 \mathrm{~B}$ & $1.77 \mathrm{~B}$ & $1.11 \mathrm{~A}$ \\
& $8 \mathrm{pl} . / \mathrm{m}^{2}$ & $42.0 \mathrm{~B}$ & $1606.67 \mathrm{C}$ & $247.23 \mathrm{C}$ & $1.44 \mathrm{D}$ & $0.19 \mathrm{C}$ & $0.95 \mathrm{C}$ & $0.48 \mathrm{~B}$ \\
\hline & & \multicolumn{7}{|c|}{ Second Season 2018 } \\
\hline \multirow{2}{*}{ Ch.N.S } & $6 \mathrm{pl} . / \mathrm{m}^{2}$ & $62 \mathrm{~A}$ & $3413.00 \mathrm{~B}$ & $524.67 \mathrm{~B}$ & $2.43 \mathrm{~A}$ & $0.45 \mathrm{~A}$ & $2.51 \mathrm{~A}$ & $1.35 \mathrm{~A}$ \\
& $8 \mathrm{pl} . \mathrm{m}^{2}$ & $60.7 \mathrm{~A}$ & $4637.33 \mathrm{~A}$ & $713.60 \mathrm{~A}$ & $1.93 \mathrm{C}$ & $0.26 \mathrm{C}$ & $1.55 \mathrm{~B}$ & $1.18 \mathrm{~A}$ \\
\hline \multirow{2}{*}{ Aqua S } & $6 \mathrm{pl} . \mathrm{m}^{2}$ & $45.3 \mathrm{~B}$ & $2004.67 \mathrm{D}$ & $308.60 \mathrm{D}$ & $2.08 \mathrm{~B}$ & $0.32 \mathrm{~B}$ & $1.89 \mathrm{~B}$ & $1.26 \mathrm{~A}$ \\
& $8 \mathrm{pl} . / \mathrm{m}^{2}$ & $46.7 \mathrm{~B}$ & $2776.00 \mathrm{C}$ & $426.93 \mathrm{C}$ & $1.73 \mathrm{D}$ & $0.22 \mathrm{C}$ & $1.15 \mathrm{C}$ & $0.62 \mathrm{~B}$ \\
\hline
\end{tabular}

* Similar letters indicate non-significant at 0.05 levels.

** Capital letters indicate the significant difference of each factor $(P<0.05)$

${ }^{* * *}$ Nutr. Source: nutrient source

${ }^{* * * *}$ Ch.N.S: chemical nutrient solution

${ }^{* * * * *}$ Aqua S.: Aquaponic solution 


\section{DISCUSSION}

Concentrations of $\mathrm{NH}^{+4}$ and $\mathrm{NO}_{3}$ were at the safe range for tilapia whether integrated with basil or mint, notwithstanding concentrations of tilapia water nutrients are lower than those ordinarily found in the nutrient solution of hydroponic systems, but they are accepted for aquaponics as they are generated from the mineralization of organic matter of tilapia and are daily produced that is because the slow disposal of tilapia excretion provides an efficient period for considerable mineralization to happen. Additionally, elimination of organic matter, microorganisms in the rearing tank, also removed dissolved organic matter, avoiding it from carrying immoderate microbial growth on the basil and mint roots. (Rakocy, 2010).

In general, the use of chemical nutrient solution provided the highest records of vegetative growth and yield characteristics, as well as $\mathrm{N}, \mathrm{P}, \mathrm{K}$ and oil content of both basil and mint during the two cultivated seasons, and this was decided upon (Shaymaa, 2017). The composition and quantities of plant nutrients in the chemical nutrient solution are compatible with the criteria for basil and mint nutrition relative to the fish water content of nutrients Valentina et al 2018. The satisfaction of nutrient requirements has led to optimum vegetative growth characteristics which have led to the highest yield as accepted (Somerville et al 2014).

Agreed with (Flowers et al 2007) in the current study, basil reported higher biomass than mint, while fresh and dry basil / $\mathrm{m} 2$ yields were higher than mint. On the other side, the nitrogen and oil content (percent) of mint yielded the highest levels compared to basil as accepted with (Dilipbhai, 2015).

As agreed with (Moya et al 2016) Increased plant density from 6 to 8 plants of both basil and mint led to an increase in fresh and dry yield $/ \mathrm{m}^{2}$ under chemical nutrient solution and fish water thus decreasing the N, P, K and oil content of both basil and mint. In addition, the plant density of both basil and mint had a significant impact on the yield of tilapia fish during the two cultivated seasons as a result of the rise in the removal of $\mathrm{N}$ forms and other nutrients from fish water Wongkiewa et al 2017. As agreed with (Yildiz et al 2017) Plants in aquaponic systems used as a bio-filter to remove soluble nutrients from fish waste and feeders. The yield of tilapia fish was generally higher under different plant basil densities Saha et al 2016, Rakocy et al 2004 than the plant density of mint. It seems that the basil had a supreme effect on the yield of tilapia fish compared to mint. These results could be explained in terms of higher fresh and dry basil yields compared to mint. Basil plants had a higher potential for removing nutrients from fish water as agreed with (Abdolhossein et al 2013)

\section{CONCLUSION}

The Aquaponic method may play a role not only in the production of food but also in the production of medicinal and aromatic herbs such as basil and mint. In the event of the need for the maximum fresh and dry yield of basil and mint with no environmental concerns, the study recommended the use of chemical nutrient solution combined with plant density 8 plants $/ \mathrm{m}^{2}$ of basil and mint. While in the case of the oil content is the target yield, chemical nutrient solution combined with plant density 6 plants $/ \mathrm{m}^{2}$ is suggested. High regard for environmental issues (free of chemical fertilizers) and production versatility, the aquaponic system with plant density 8 plants $/ \mathrm{m}^{2}$ of basil and mint for fresh and dry yield or plant density 6 plants / $\mathrm{m} 2$ for oil content are recommended. The basil plants provide a higher capacity for removing the nutrients of fish rearing water compared with mint. The need to investigate more plants to estimates the higher plant capacity for removing the nutrients efficiently led to increasing the aquaponic system production (fish and plant).

\section{REFERENCE}

Abdolhossein A., Marzeh G.J. and Mehdi H.F. 2013. Evaluation of growth and yield of organically-grown basil (Ocimum basilicum L.) in soilless culture. J. of Food, Agric. \& Environment 11(1), 299-301.

Abul-Soud M.A., Emam M.S.A., Maharik Z.Y., Mohammed M.H. and Hawash A.M.H. 2017. How to sustain ecology food production under urban condition. Zagazig J. Agric. Res., 44(4), 1259-1276.

Allen S.E. The satisfaction 1974. Chemical Analysis of Ecological Materials. Black-Well, Oxford, $565 \mathrm{p}$.

Bernstein S. 2011. Aquaponic gardening: a stepby-step guide to raising vegetables and fish together. Gabriola Island, Canada: New Society Publishers, pp. 98-190. 

into the Aquaponic Tilapia production system

Carlo B., Greta G. and Baldassare F. 2016. From freshwater to marine aquaponic: new opportunities for marine fish species production, pp. 514521.

Carlson D. 2013. Aquaponic systems: Potentials On northern latitude, mid Sweden University Department of Eco technology and Sustainable Building Engineering pp. 1-35.

Chambers H. 1992. Mentha: Genetic resources and the collection at USDA-ARSNCGR- Corvallis. Lam Newsl. 1, 3-4.

Chapman H.D. and Pratt P.F. 1962. "Methods of Analysis for Soil, Plants and Water". Univ. California, Barreley, CA, USA.

D'Abramo L.R. and Brunson M.W. 1996. Production of freshwater prawns in ponds. Southern Regional Aquaculture Center (SRAC) Publication No. 484.

Dilipbhai P.S. 2015. Clonal propagation of mentha using different media, Navsari - 396 450, 1-103.

El-Sayed A.FM. 2006. Tilapia culture. CABI Publishing, CABI International Willingford, Oxfordshire, UK. 348 p.

FAO .1980. Soil and Plant Analysis. Soils Bulletin, 38, 242-250.

FAO. 2010. The State of World Fisheries and Aquaculture 2010. Rome, FAO. 2010. 197 p.

FAO 2012. Small-scale aquaponic food production. FAO fisheries and Aquaculture technical paper, Rome, Italy, 589 p.

Flowers T.J., Uliana B. and Katerina S. 2007. Herbs: Pre and Post-harvest factors affecting shelf life, flavor, yield and quality, P1:74. University of Sussex, Project number: Fv 290.

Harley R.M. and Brighton C.A. 1977. Chromosome number in the genus Mentha L. Bot J. Linn Soc. 74, 71-96.

Jackson M.L. 1958. "Soil Chemical Analysis". Prentic-Hall, Inc. Englewood Cliffs, N.J. Library of Congress, USA.

Moya E.A.E., Sahagun C.A.A., Carrillo J.M.M., Alpuche P.J.A., Alvarez-Gonz_alez C.A. and Mart_ınez-Y_a nez R. 2016. Herbaceous plants as part of biological filter for aquaponics system, Aquaculture Research, 47, 17161726.

Radosavljević V., Ćirković M., Ljubojević D., Akić-Dimić D., Marković3 Z., Zutić1 J. and Milićević1 V. 2014. Searching for solutions in aquaculture: aquaponics, Arhiv veterinarske medicine, 7(2), 71-78.

Rakocy 2010. "Update on tilapia and vegetable production in the UVI aquaponic system". P 1:16,
University of the Virgin Islands Agricultural Experiment Station RR 2, Box 10,000 Kingshill, VI 00850, USA.

Rakocy J.E., Shultz R.C., Bailey D.S. and Thoman E.S. 2004. Aquaponic production of tilapia and basil: comparing a batch and staggered cropping system. Acta Horticulturae (ISHS) 648, 63-69.

(http://www.actahort.org/books/648/648 8.htm)

Rivera-Ferre M., Ortega-Cerdà $M$. and Baumgärtner J. 2013. Rethinking Study and Management of Agricultural Systems for Policy Design, Sustainability, 5, 3858-3875.

Rossana S. 2016. "Important Water Quality Parameters in Aquaponics Systems" p .1:8, Extension Aquatic Ecology Specialist, Department of Extension Animal Sciences and Natural Resources, New Mexico State University.

Saha 2016. Growth, yield, plant quality and nutrition of basil (Ocimum basilicum L.) under soilless agricultural systems, Annals of Agricultural Science (2016), 6 p.

Selek M., Endo M., Yiğit M. and Takeuchi T. 2017. The Integration of Fish And Plant Production: Nile Tilapia (Oreochromis Niloticus) and Basil (Ocimum Basilicum) Culture in Recirculating and Aquaponic Systems, J. of Aquaculture Engineering and Fisheries Research, 3(1), 2843.

Shaymaa 2017. Physiological effects of mycorrhizae, magnetite and humic acid on basil plants grown under different levels of chemical fertilizers, pp. 1-15, 7720-15117-1-SM.

Skar 2015. Aquaponics NOMA New Innovations for Sustainable Aquaculture in the Nordic Countries, Nordic Innovation publication 2015:06, pp. 1-108.

Snedicor G.W. and Cochran W.G. 1981. Statistical methods. 7th lowa State Univ. Press, lowa, USA, pp. 225-320.

Somerville C., Cohen M., PanNH4ella E., SNH4kus A. and Lovatelli A. 2014. Smallscale aquaponic food production: Integrated fish and plant farming. FAO Fisheries and Aquaculture Technical Paper; Rome (2014): 1-19, 21-81, 83-121,123-139,141-155,157-161,163167,169-181,183-189,191-203,205-207,209247, 249-265.

Sumeth W., Zhen H., Kartik C., Jae W.L.D. and Samir K.K. 2017. "Nitrogen transformations in aquaponic systems: A Review" Aquacultural Engineering 76, 9-19.

Thorarinsdottir R.I. 2015. Aquaponics guidelines, Haskolaprent, Iceland. 69 p. 
Tidwell J.H. and Allan G. 2012. The role of Aquaculture. In: Aquaculture Production Systems. Hoboken, NJ, USA: Tidwell, J.H. Ed, John Willey \& Sons, $434 \mathrm{p}$.

Valentina N., Andreas G., Zala S., Alex M. and Ranka J. 2018. "Nutrient Management in Aquaponics: Comparison of Three Approaches for Cultivating Lettuce, Mint and Mushroom Herb", Agronomy 2018, 8, 27; doi:10.3390/agronomy8030027, 15 p.

WaNH4abe F.S. and OIsen S.R. 1965. Test of an ascorbic acid method for determining phosphorous in water and $\mathrm{NaHCO}_{3}$ extracts from soil. Soil Sci. Soc. Am. Proc. 29, 677- 678.

Wilson L. 2017. Comparing Basil (Ocimum Basilicum). Production In Hydroponic and Aquaponic Systems. $47 \mathrm{p}$.

Wogiatzi E., Papachatzis A., Kalorizou H., Chouliara A. and Chouliaras N. 2011. Evaluation of Essential Oil Yield and Chemical Com- ponents of Selected Basil Cultivars, Biotechnology \& Biotechnological Equipment, 25(3), 2525-2527.

WHO. How to Develop and Implement a National Drug Policy, 2nd ed. Geneva: WHO, 2001.WHO, 2002 (WHO Policy Perspectives on Medicine, No. 5) (WHO/ EDM/2002.3).

Worldometer 2020. http://www.worldometers.info Yigit M., Celikkol B., Bulut M., DeCew J., Ozalp B., Yilmaz S., Kaya H., Kizilkaya B., Hisar O., Yildız H., Yigit Ü., Sa- hinyilmaz M. and Dwyer R.L. 2016. Monitoring of trace metals, biochemical composition and growth of Axillary sea-bream (Pagellus acarne Risso, 1827 ) in an offshore copper alloy mesh cages. Mediterranean Marine Sci., 17(2), 396-403.

Yildiz 2017. "Fish Welfare in Aquaponic Systems: Its Relation to Water Quality with an Emphasis on Feed and Faeces-A Review" Water 2017, 9, 13; doi:10.3390/w9010013 
تقييم إنتاج أعشاب النعناع والريحان بالتكامل مع إنتاج أسماك البلطى بنظام الاكوابونك

[41]

$$
\begin{aligned}
& \text { صباح عبد الكريم محمود سلامة1" - عواض محمد قنديل2 - محمد زكي الثناوي22 - }
\end{aligned}
$$

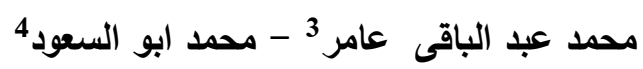

1- برنامج الزراعة العضوية باللغة الإنجليزية - كلية الزراعة - جامعة عين شمس - ص.ب 68 - حدائق شبرا 11241 -

$$
\begin{aligned}
& \text { القاهرة - مصر } \\
& \text { 2- قسم البساتين - كلية الزراعة - جامعة عين شمس - ص.ب } 68 \text { - حدائق شبرا } 11241 \text { - القاهرة - مصر }
\end{aligned}
$$

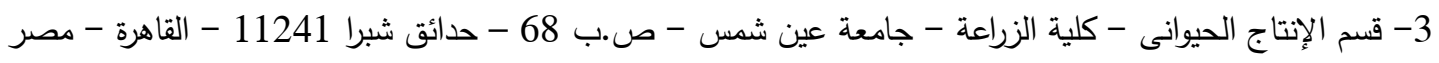

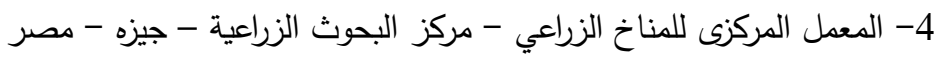

*Corresponding author: sabahsalama28@yahoo.com

والعطرية مثل الريحان والنعناع، توصى الدراسة للحصول

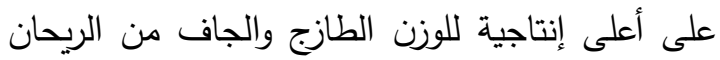

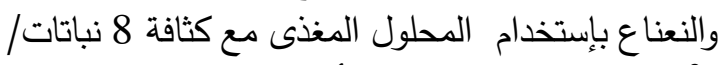

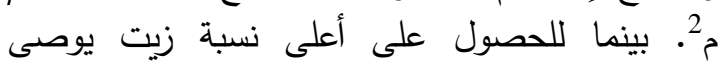
بإستخدام المحلول المغذى مع كثافة 6 نباتات/2².

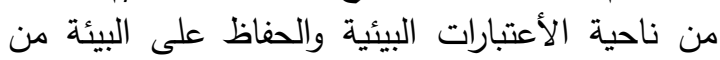

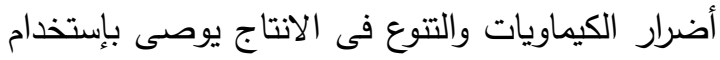

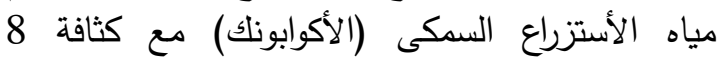

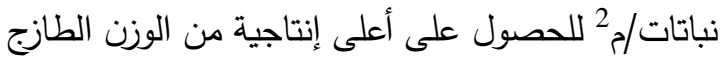

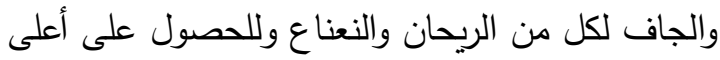

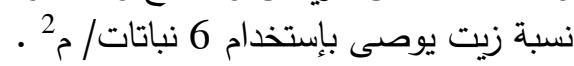

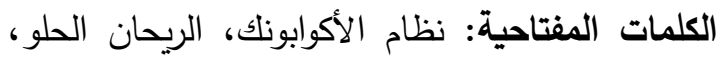

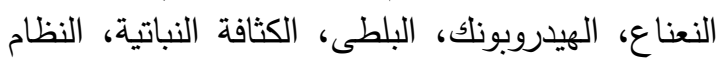

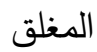

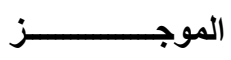

أجريت هذه التجربة فى معهد الدراسات العليا

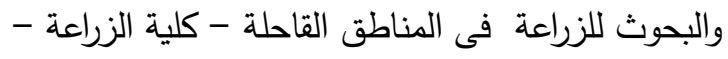

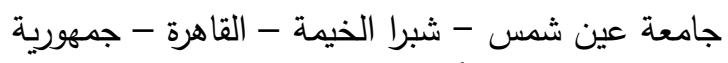
مصر العربية، من أجل إستخدام نظام تكاملى لإنتاج

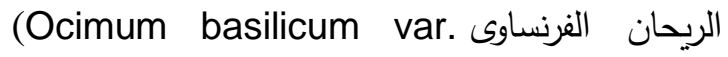

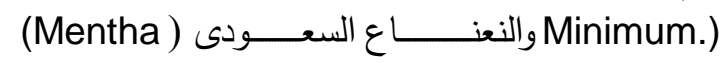
longifolia و 2018 على التوالي. وتم إستخدام كثافتين لكل من فئن

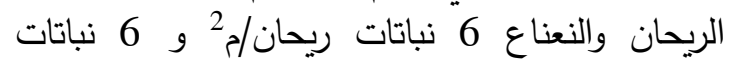

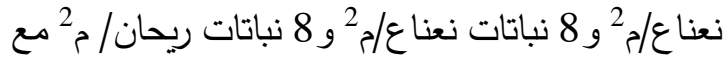

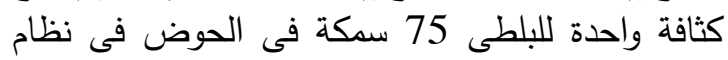

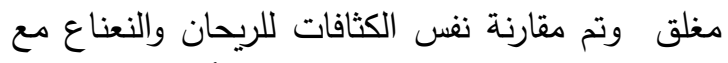

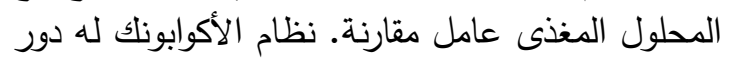

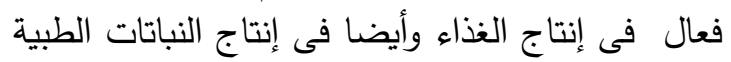

